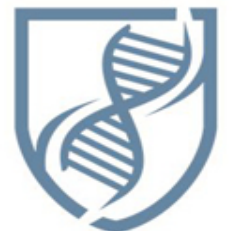

Journal of Bioscience and Applied Research

\section{JBAAR}

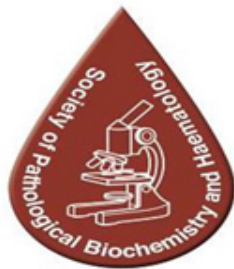

WWW.JBAAR.ORG

\title{
Effect of Doping a Rare-Earth Oxide on the Photovoltaic Parameters of Dye -Sensitized Solar Cells
}

\author{
A. A. El-Hamalawy, M. M. El-Kholy, Alshimaa Ali \\ Physics Department, Faculty of Science, Minufiya University, Shebin El-Kom, Minufiya 32511, Egypt. \\ (Corresponding author-email: ahamalawy@hotmail.com)
}

\begin{abstract}
$\mathrm{Yb}_{2} \mathrm{O}_{3}$-doped $\mathrm{TiO}_{2}$ were prepared using mechanochemical process to obtain Dye Sensitized Solar Cells (DSSCs) photoanodes. The parameters of DSSC devices were calculated. The study showed that the addition of $\mathrm{Yb}_{2} \mathrm{O}_{3}$ improved the open-circuit voltage via a p-type effect, whereas, a negative effect on the generated photocurrent was observed. This reduction in photocurrent was attributed to increasing crystal defects as a result of increasing the concentration of $\mathrm{Yb}_{2} \mathrm{O}_{3}$ dopants.
\end{abstract}

Keywords: Dye Sensitized Solar Cells, $\mathrm{Yb}_{2} \mathrm{O}_{3}$, P-type

\section{Introduction}

Earth receives $120000 \mathrm{TW}$ of solar power, whereas, the global energy consumption is only $15 \mathrm{TW}$. Therefore, solar energy hold great considerable potential for addressing the world's growing energy need (Gratzel et al., 2012). An enormous effort has been devoted to Dye Sensitized Solar Cells (DSSCs) due to its low cost production, environmentally friendly components and relatively high conversion efficiency (Heimer et al., 2000, Yang et al., 2008). Typically, DSSC consists of a working electrode, iodine based redox-couple electrolyte and a counter electrode coated with a platinum layer (O'regan and Graetzel, 1991, Grätzel , 2001, Mansa et al., 2013).

The semiconductor (working) electrode is a crucial component of DSSCs as it mainly controls its performance. So, many studies focus on doping $\mathrm{TiO}_{2}$ photoanode of DSSC to improve the efficiency of DSSCs (Wang et al., 2012).
For the metal-doped $\mathrm{TiO}_{2}$ nanomaterials, $\mathrm{Lü}$ and coworker (2010) reported that DSSC based on the Nbdoped $\mathrm{TiO}_{2}$ photoelectrode showed an improved shortcircuit current density. This improvement was related to the ability of charge transfer and to an increase in electron concentration due to Nb-doping. Also, the doping of $\mathrm{TiO}_{2}$ with low valent metallic element was investigated (Wang, et al., 2012). Whereas, Sb-doped $\mathrm{TiO}_{2}$ showed an improvement of the performance of DSSC due enhancement of the short-circuit current density. For N-doping, $\mathrm{TiO}_{2}$ photoelectrode confirmed higher photoelectric performance than that of pure $\mathrm{TiO}_{2}$ photoelectrode (Qin et al., 2013).

Doping of $\mathrm{TiO}_{2}$ with multielements (B, C, N and F) enhanced the efficiency of DSSCs, as reported by Im et al. (2012). This enhancement was attributed to a reduction in the recombination of electrons (in the conduction band of $\mathrm{TiO}_{2}$ ) with the dye and/or electrolyte. Furthermore, Yang et al. (2012) reported that the photoelectric conversion efficiency of N3-sensitized N-doped and F-doped $\mathrm{TiO}_{2}$ electrodes was about $17.1 \%$ higher than that of a pure $\mathrm{TiO}_{2}$ electrode. Also, bisemiconductors of $\mathrm{TiO}_{2}$ and $\mathrm{Fe}_{2} \mathrm{O}_{3}$ were used as photoelectrodes of DSSC devices (Im et al., 2011). The use of these bisemiconductors caused an increase in the efficiency and was attributed to a cocktail effect of the two conduction bands.

Rare-earth-doped compounds have been the subject of extensive research, as well. Hafez et al. (2011) reported that Lanthanide $\left(\mathrm{Ln}^{3+}\right)$-doped $\mathrm{TiO}_{2}$ enhanced the efficiency of DSSCs. In the current work, we have investigated the influence doping titanium(IV) oxide photoanodes with 
ytterbium(III) oxide on the efficiency of DSSCs.

\section{Experimental Part}

\subsection{Materials}

Chemicals and materials including titanium dioxide (BHD, 98.0\%), distilled water, acetyl acetone (Elnaser pharmaceutical chemical, 98.0\%), triton X100 (El- goumhouria), terpanol (Alpha Chemie, 95.5\%), ethylene glycol (SDFCL), iodine resublimed (Elnaser pharmaceutical chemical), potassium iodide (Elnaser pharmaceutical chemical, 99.5\%), N719 dye (Dyesol) and FTO (fluorine doped $\mathrm{SnO}_{2}$ coated glasses (Dyesol, 15 $2 /$ sq.m) were used.

\subsection{Materials Preparation}

a) Preparation of $\mathrm{TiO}_{2}$ Paste: We added $1.5 \mathrm{ml}$ of distilled water to $1 \mathrm{gm}$ of titanium dioxide nanoparticles. Then, $0.1 \mathrm{ml}$ of triton X-100, $0.1 \mathrm{ml}$ of acetyl acetone and a drop of terpanol was added to the mixture. The final solution was hold under continuous stirring for $24 \mathrm{~h}$.

b) Preparation of $\mathrm{Yb}_{2} \mathrm{O}_{3}-$ Doped $\mathrm{TiO}_{2}$ Paste: $\mathrm{Yb}_{2} \mathrm{O}_{3}-$ doped $\mathrm{TiO}_{2}$ was prepared via a method similar to nondoped $\mathrm{TiO}_{2}$ preparation process described above. However, the only difference was adding $\mathrm{Yb}_{2} \mathrm{O}_{3}$ powder (ground for $1 \mathrm{~h}$ ) with different concentrations $\left[\left(\mathrm{Yb}_{2} \mathrm{O}_{3}\right)_{\mathrm{x}}-\left(\mathrm{TiO}_{2}\right)_{1-\mathrm{x}}\right.$ where $\mathrm{x}=2 \%$, and $\left.6 \%\right]$ to $\mathrm{TiO}_{2}$ powder during the initial stage of the preparation process.

c) Preparation of Film Electrodes and Assembly of the DSSCs: The paste was spread on the conductive side of the substrate using a doctor-blade technique. The film was sintered at $450{ }^{\circ} \mathrm{C}$ for $30 \mathrm{~min}$. After cooling down to room temperature, the substrate was soaked in an ethanol solution of N-719 for $24 \mathrm{~h}$ to absorb the dye adequately. The DSSC was assembled by injecting the electrolyte $(50 \mathrm{ml}$ of ethylene glycol, $0.635 \mathrm{gm}$ of $\mathrm{I}_{2}, 4.15 \mathrm{gm}$ of $\mathrm{KI}$ in acetonitrile) into the aperture between the $\mathrm{TiO}_{2}$ electrode (anode electrode) and the platinum-coated counter electrode. The two electrodes were clipped together by an adhesive tape (parafilm) to prevent the electrolyte solution from leaking.

\section{Measurements and Characterization}

The photocurrent density-voltage $(\mathrm{J}-\mathrm{V})$ measurement was tested using a source meter (Keithley Instruments, Inc.), digit multimeter-counter (Modle1087- APLAB), homemade device holder and solar simulator irradiation with Xe (55 W) Lamp. The tested solar cells were masked to a working area of about $0.2 \mathrm{~cm}^{2}$.

\section{Results and Discussion}

The photocurrent density-voltage $(\mathrm{J}-\mathrm{V})$ curves of DSSCs with $\left(\mathrm{Yb}_{2} \mathrm{O}_{3}\right)_{\mathrm{x}}-\left(\mathrm{TiO}_{2}\right)_{1-\mathrm{x}}$ photoanodes with different concentrations of $\mathrm{Yb}_{2} \mathrm{O}_{3}(\mathrm{x}=0 \%, 2 \%$ and $6 \%)$ under simulated solar irradiation are were in Figure 1 . As seen, the lowest value of open-circuit voltage $\left(\mathrm{V}_{\text {oc }}\right)$ corresponds to the DSSC of the undoped photoelectrode $\left(\mathrm{V}_{\mathrm{oc}}=0.453 \mathrm{~V}\right.$ for $\left.\mathrm{x}=0.0\right)$. Moreover, $\mathrm{V}_{\text {oc }}$ increases with increasing of the concentration of $\mathrm{Yb}_{2} \mathrm{O}_{3}\left(\mathrm{~V}_{\mathrm{oc}}=0.462 \mathrm{~V}\right.$ for $\left.\mathrm{x}=0.02 \%\right)$ and had the largest value $\left(\mathrm{V}_{\mathrm{oc}}=0.475 \mathrm{~V}\right)$ for the highest concentration $(x=6 \%)$. Therefore, we conclude that the $\mathrm{V}_{\text {oc }}$ increased gradually with the increase of doping and this effect can mainly be ascribed to the ptype effect. According to published reports (Gratzel, M., 2009, Hagfeldt et al., 2010), $V_{\text {oc }}$ has been determined by the difference between the quasi-Fermi level of photoanode and the redox potential of electrolyte. Consequently, when $\mathrm{Yb}^{3+}$ ions substitutes $\mathrm{Ti}^{4+}$ ions, a p-type doping effect occurs as the quasiFermi level will be shifted upward and hence $V_{\text {oc }}$ will increase (Ko et al., 2005). Also, it was noted from J-V curves that the short-circuit photocurrent density $\left(\mathrm{J}_{\mathrm{sc}}\right)$ had the largest value for undoped DSSC $(\mathrm{x}=0.0)$ and decreased by increasing the doping percent of $\mathrm{Yb}_{2} \mathrm{O}_{3}$. The reason of this behavior could be attributed to the fact that $\mathrm{Yb}_{2} \mathrm{O}_{3}$ impurities produce more crystal defects and those defects can capture photoinduced electrons, hence the photocurrent decreases (Ko et al., 2005, Murakoshi et al., 1995).

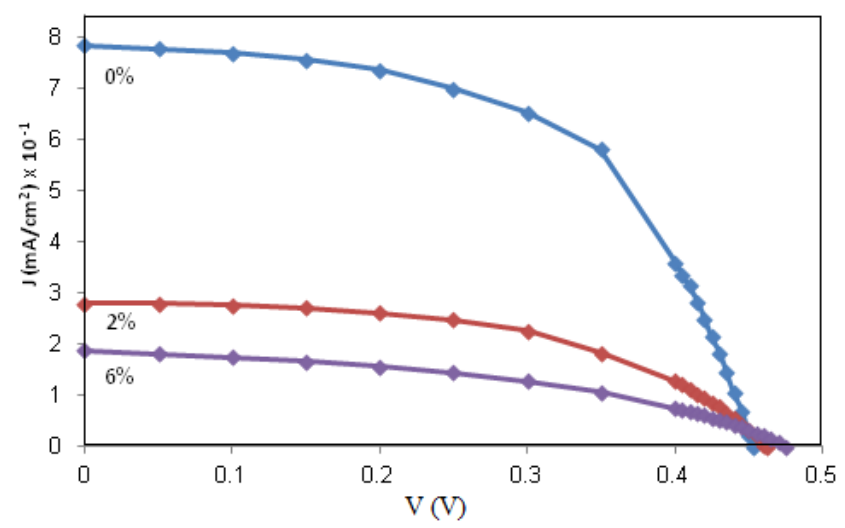

Figure 1: The photocurrent density-voltage $(\mathrm{J}-\mathrm{V})$ curves of DSSCs with different $\mathrm{Yb}_{2} \mathrm{O}_{3}$ concentrations. 


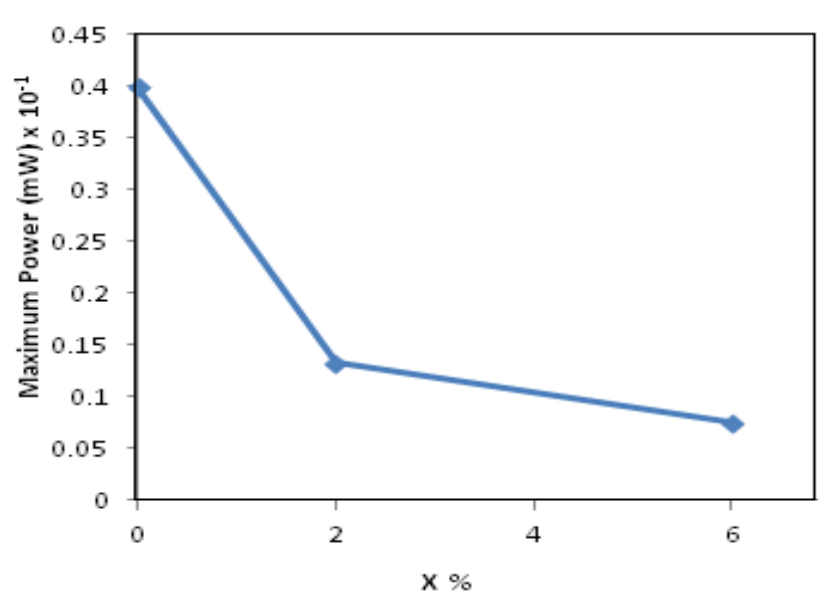

Figure 2: Variation of maximum power of DSSC devices with $\mathrm{Yb}_{2} \mathrm{O}_{3}$ concentration with $\mathrm{x}=0 \%, 2 \%$ and $6 \%$.

The maximum power and doping concentration relation was shown in Figure 2. As shown, the maximum power decreased by increasing the doping concentration and this referred to the large decrease in photocurrent by increasing of $\mathrm{x}$.

The photovoltaic parameters were calculated and indicated in Table 1. The fill factor (FF) is a measure of ideality of a solar cell. The fill factor was calculated using the equation:

$$
\boldsymbol{F F}=\frac{V_{\max } \boldsymbol{J}_{\max }}{\boldsymbol{V}_{o c} \boldsymbol{J}_{s c}}
$$

where $\mathrm{V}_{\max }$ and $\mathrm{J}_{\max }$ are the voltage and current at the point of maximum output power in J-V curves. The values of fill factors for DSSCs with different concentration of the dopant were calculated and indicated in Table 1. It was noted that FF decreases by increasing the concentration of dopant as the series resistance $\left(R_{s}\right)$ increases. This means that to the value of contact resistance and transfer resistance in the semiconductor material $\left(\mathrm{TiO}_{2}\right)$ increased which corresponded to the lower value of produced photocurrent. Accordingly, the efficiency of the cell also decreases with doping, as shown in Table 1. The overall light-to-electrical energy conversion efficiency $(\eta)$ of DSSC was calculated according to the following equation:

$$
\eta=\frac{P_{\max }}{P_{i n}}=\frac{V_{o c} I_{s c} F F}{P_{i n}}
$$

where $P_{\max }$ is the generating maximum power and $P_{\text {in }}$ is the input power of the incident light on the active area of the cell .
Table 1: The photovoltaic parameters of DSSC devices with different concentrations of $\mathrm{Yb}_{2} \mathrm{O}_{3}$ powder, $\mathrm{x}$.

\begin{tabular}{ccccccc}
\hline$x(\mathrm{wt} . \%)$ & $\mathrm{V}_{\infty}(\mathrm{V})$ & $\begin{array}{c}\mathrm{J}_{y \varepsilon}\left(\mathrm{mA} / \mathrm{cm}^{2}\right) \\
\times 10^{-1}\end{array}$ & $\mathrm{~V}_{\max }(\mathrm{V})$ & $\begin{array}{l}\mathrm{J}_{\max }\left(\mathrm{mA} / \mathrm{cm}^{2}\right) \\
\times 10^{-1}\end{array}$ & $\mathrm{FF}$ & $\eta(\%)$ \\
\hline 0 & 0.453 & 7.83 & 0.350 & 5.807 & 0.573 & 4.060 \\
2 & 0.462 & 2.789 & 0.300 & 2.257 & 0.525 & 1.360 \\
6 & 0.475 & 1.871 & 0.300 & 1.28 & 0.432 & 0.76 \\
\hline
\end{tabular}

\section{Conclusion}

In summary, $\mathrm{Yb}_{2} \mathrm{O}_{3}$ was introduced into $\mathrm{TiO}_{2}$ photoanode of a dye-sensitized solar cell. Yb-doping improved $V_{\text {oc }}$ via its p-type dopant effect; shifts the energy level of the $\mathrm{TiO}_{2}$ oxide film up and consequently increases the photovoltage. As more crystal defects introduced by increasing the concentration of $\mathrm{Yb}_{2} \mathrm{O}_{3}$ dopants; more photoinduced electrons were captured and hence photocurrent was decreased. The solar conversion efficiency of $\mathrm{Yb}$ doped DSSC devices is lower than that of the undoped DSSCs..

\section{References}

Graetzel, M., Janssen, R. A., Mitzi, D. B., Sargent, E. H. (2012). Materials interface engineering for solutionprocessed photovoltaics. Nature, 488 (7411), 304-312.

Grätzel, M. (2001). Photoelectrochemical cells. Nature, 414(6861), 338-344.

Grätzel, M. (2009). Recent advances in sensitized mesoscopic solar cells.Accounts of chemical research, 42(11), 1788-1798.

Hafez, H., Saif, M., Abdel-Mottaleb, M. S. A. (2011). Down-converting lanthanide doped $\mathrm{TiO} 2$ photoelectrodes for efficiency enhancement of dye-sensitized solar cells. Journal of Power Sources, 196(13), 5792-5796.

Hagfeldt, A., Boschloo, G., Sun, L., Kloo, L., Pettersson, H. (2010). Dye-sensitized solar cells. Chemical reviews, 110(11), 6595-6663.

Heimer, T. A., Heilweil, E. J., Bignozzi, C. A., Meyer, G. J. (2000). Electron injection, recombination, and halide oxidation dynamics at dye-sensitized metal oxide interfaces. the Journal of Physical Chemistry A, 104(18), 4256-4262.

Im, J. S., Lee, S. K., Lee, Y. S. (2011). Cocktail effect of $\mathrm{Fe} 2 \mathrm{O} 3$ and $\mathrm{TiO} 2$ semiconductors for a high performance dye-sensitized solar cell.Applied Surface Science, 257(6), 2164-2169.

Im, J. S., Yun, J., Lee, S. K., Lee, Y. S. (2012). Effects of multi-element dopants of TiO 2 for high performance in dye-sensitized solar cells. Journal of Alloys and Compounds, 513, 573-579.

Lü, X., Mou, X., Wu, J., Zhang, D., Zhang, L., Huang, F., Huang, S. (2010). Improved Performance Dye 
Sensitized Solar Cells Using Nb Doped TiO2 Electrodes: Efficient Electron Injection and Transfer. Advanced Functional Materials, 20(3), 509-515.

Mansa, R. F., Yugis, A. R. A., Liow, K. S., Chai, S. T. L., Ung, M. C., Dayou, J., Sipaut, C. S. (2013). A Brief Review on Photoanode, Electrolyte, and Photocathode Materials for Dye-Sensitized Solar Cell Based on Natural Dye Photosensitizers. In Developments in Sustainable Chemical and Bioprocess Technology , Springer US , 313319.

Murakoshi, K., Kano, G., Wada, Y., Yanagida, S., Miyazaki, H., Matsumoto, M., Murasawa, S. (1995). Importance of binding states between photosensitizing molecules and the TiO 2 surface for efficiency in a dyesensitized solar cell. Journal of Electroanalytical Chemistry, 396(1), 27-34.

O'regan, B., Graetzel, M. (1991). A low-cost, highefficiency solar cell based on dye-sensitized. nature, 353(6346), 737-740.

Qin, W., Lu, S., Wu, X., Wang, S. (2013). Dyesensitized solar cell based on N-doped TiO 2 electrodes prepared on titanium. Int J Electrochem Sci, 8, 7984-7990.

Wang, M., Bai, S., Chen, A., Duan, Y., Liu, Q., Li, D., Lin, Y. (2012). Improved photovoltaic performance of dyesensitized solar cells by Sb-doped TiO 2 photoanode. Electrochimica Acta, 77, 54-59.

Yang, S., Xue, H., Wang, H., Kou, H., Wang, J., Zhu, G. (2012). Improved efficiency of dye-sensitized solar cells applied with nanostructured $\mathrm{N}-\mathrm{F}$ doped TiO 2 electrode. Journal of Physics and Chemistry of Solids, 73(7), 911916.

Yang, Y., Zhou, C. H., Xu, S., Hu, H., Chen, B. L., Zhang, J., Zhao, X. Z. (2008). Improved stability of quasisolid-state dye-sensitized solar cell based on poly (ethylene oxide)-poly (vinylidene fluoride) polymer-blend electrolytes.Journal of Power Sources, 185(2), 1492-1498. 